\title{
Sinais dos tempos, sinais dos lugares: reconfigu- raçóes dos modos como heterossexuais pensam os gostos sexuais de homossexuais
}

\author{
Elias Evangelista Gomes \\ Universidade Federal de Alfenas
}

\begin{abstract}
RESUMO: A partir de uma etnografia realizada em uma igreja evangélica da cidade de São Paulo (Brasil), este artigo discute os nexos entre religiáo e sexualidade no contexto urbano. Por meio do que dizem alguns jovens heterossexuais autodeclarados frequentadores da igreja em questão, foi possível refletir sobre os aspectos de classificação, hierarquização e julgamento relacionados aos gostos sexuais dissidentes. Mais especificamente, procura-se aqui analisar a emergência e o declínio de cosmologias, discursos e estratégias socializadoras sobre a homossexualidade entre evangélicos. Examinam-se também os modos de se conceber e de se relacionar com as dissidências em torno das moralidades e das expressóes da sexualidade no interior da igreja e nos ambientes urbanos de sociabilidade. $\mathrm{O}$ artigo apresenta, por fim, uma reflexão sobre a circulação de pessoas entre mundos sociais distintos e sobre os modos como esses jovens reconfiguram os sentidos de religião e sexualidade.

PALAVRAS-CHAVE: Gosto sexual, homossexualidade, juventude, evangélicos, socialização.
\end{abstract}

\section{Sinais iniciais}

Neste artigo $^{1}$, pretendo refletir sobre os impactos da cosmologia evangélica e das cenas urbanas nas concepçóes acerca da homossexualidade entre jovens rapazes heterossexuais autodeclarados. ${ }^{2}$ Os jovens pesquisados, com idade entre 18 e 25 anos, são moradores da periferia paulistana 
ELIAS EVANGELISTA GOMES. SINAIS DOS TEMPOS; SINAIS DOS LUGARES...

e encontram-se com a homossexualidade, seus sujeitos e suas práticas, na igreja e em uma regiấo central da metrópole. ${ }^{3}$ Assim, busco rastrear entre eles as configuraçôes (Elias, 1970) e possíveis reconfiguraçóes dos modos de entender e classificar os gostos sexuais pelo mesmo sexo. ${ }^{4} \mathrm{An}-$ tes, porém, farei uma breve digressão teórica e empírica.

Em 2006, conclui uma pesquisa sobre práticas culturais entre jovens de uma comunidade evangélica na periferia da cidade de Belo Horizonte. Em 2007, iniciei um estudo sobre práticas de socialização entre os jovens da Comunidade Evangélica Sara Nossa Terra, localizada em um dos principais centros da cidade de São Paulo. ${ }^{5}$ Em Belo Horizonte, observei que existiam na igreja os seguintes pontos de tensão em relação aos jovens: estética, sexualidade e comportamento litúrgico (Gomes, 2007a, 2007b). Em Sáo Paulo, observei outros três focos: formação de lideranças, sexualidade e comportamento ético. Essas diferenças referiam-se basicamente ao perfil denominacional das duas igrejas: enquanto a primeira, da periferia, combinava as características de um pentecostalismo clássico (Mariano, 1999) com as de um neopentecostalismo rústico (Almeida Junior, 2008), mais ligado aos pobres e às camadas populares, preservando princípios estéticos restritivos às mulheres e aos homens, elementos de magia nos cultos (Oro, 1997) e explicaçóes prioritariamente espirituais para as dissidências sexuais, a segunda, do centro paulistano, possuía características de um alto pentecostalismo (Almeida Junior, 2008), mais ligado às elites e camadas médias, focadas em explicaçóes psicologizantes baseadas em um construtivismo moral sobre sexualidade (Natividade e Oliveira, 2004) que retratarei mais adiante. ${ }^{6}$

Parti para o campo, na metrópole paulistana, com um conhecimento teórico que sinalizava uma reconfiguração do processo socializador de jovens brasileiros fundada na interdependência de instâncias sociais como religião, escola, mídia e família, coexistindo projetos institucionais confluentes e concorrentes (Setton, 2002, 2005, 2009). 
REVISTA DE ANTROPOLOGIA, SÃO PAULO, USP, $20 \mathrm{I}$, V. 58 N $\mathrm{N}^{\mathrm{O}} \mathrm{I}$.

Esses jovens da pesquisa em São Paulo, antes da adesão à Comunidade Evangélica Sara Nossa Terra, transitaram por outras igrejas vinculadas ao ou com alguma hibridação com o - neopentecostalismo; entre elas, batistas renovadas, Quadrangular, Assembleia de Deus, Igreja Universal do Reino de Deus e outras denominaçôes. É possível compreender os perfis de condição de classe social desses jovens por suas características comuns: já finalizaram o ensino médio ou estão em processo de entrada ou cursando o ensino superior; trabalham para estudar ou são bolsistas de programas públicos de financiamento; ajudam em casa com parte de seus salários, mas não são os principais contribuintes; têm condiçóes de consumo de roupas (mas não usam marcas muito caras) e equipamentos de telefonia e eletrônicos; frequentam cinema para assistir a filmes produzidos majoritariamente em Hollywood, mas suas principais atividades de finais de semana são religiosas; não têm costume de viajar para fora do Estado de São Paulo, exceto para eventos da igreja; náo têm carro próprio; seus pais e suas mães, nem todos evangélicos e nenhum frequentador assíduo da comunidade evangélica pesquisada, sáo trabalhadores empregados em serviços pouco prestigiados e de baixa a média remuneração; são filhos únicos ou têm no máximo três irmãos; todos são solteiros, sem filhos e vivem com suas famílias, que oscilam entre pais heterossexuais casados e mulheres heterossexuais separadas.

Depois de alguns meses em campo, escutando as falas dos jovens, resolvi levar a sério as expressóes deles: "eu gosto de mulher"; "eu gosto de menino"; "eu gosto de homem, mas acho que, um dia, vou casar com mulher"; "já senti atração por mulher, mas eu gosto mesmo é de homem". Levar a sério o que dizem os nativos é refletir teoricamente sobre os condicionamentos que fazem uma pessoa dizer que gosta mais disso ou daquilo, deste ou daquele tipo de relação afetiva e sexual. Portanto, a categoria gosto é uma categoria nativa que busco interpelar teoricamente neste artigo a partir da análise acerca das compreensóes sobre homossexualidade entre jovens evangélicos. 
ELIAS EVANGELISTA GOMES. SINAIS DOS TEMPOS; SINAIS DOS LUGARES...

Com o propósito de formular minha conceituação acerca do gosto sexual para pensar a socialização da juventude e da sexualidade, recorro à obra de Pierre Bourdieu (2003, 2008), que, de forma sistematizada, analisa o gosto aplicado às práticas de cultura de classe na Europa, sobretudo na França. ${ }^{7}$ Bourdieu (2008) considera que o gosto é uma construção social revelada como prática de cultura, resultante de condiçôes específicas de socialização. Isto é, para haver gostos, é preciso existir bens classificados, tais como bom ou mau gosto, distintos ou vulgares. Tais bens são, concomitantemente, classificados e classificatórios, hierarquizados e hierarquizantes, sendo as pessoas portadoras dos princípios de classificação de gostos e de determinação a respeito dos bens que lhes convêm e não convêm. Nesse sentido, compreendo que os discursos sobre sexualidade expressam as categorias do pensamento que julgam, hierarquizam e orientam socialmente os gostos sexuais, manifestando-se no corpo, nas interaçôes sociais e no interesse erótico.

Atento o leitor para o fato de que o construto gosto sexual náo serve como substituto dos termos "orientação", "condição" ou "opção sexual", mas sim como uma articulação teórica para pensar o processo de socialização da sexualidade de forma a implicar diferentes modos de os sujeitos entenderem as suas sexualidades e as dos outros. A meu ver, a categoria gosto, aplicada à sexualidade, permite pensar a flexibilidade, a provisoriedade das experiências sociais dos sujeitos e a fixaçáo da disposição sexual no habitus. Do ponto de vista antropológico, coloca-se em xeque a máxima de que "gosto não se discute". A seguir, mostraremos que, no universo pesquisado da igreja evangélica, o gosto sexual se discute e como ele compóe os modos de classificação, hierarquização e julgamento. 
REVISTA DE ANTROPOLOGIA, SÃO PAULO, USP, $20 \mathrm{I} 5$, V. $58 \mathrm{~N}^{\circ} \mathrm{I}$.

\section{O encontro com a homossexualidade na igreja}

Caderno de campo: Na sexta-feira, foi organizada, no templo, uma festa chamada Arena Pulse, com música eletrônica. Os jovens líderes, seguindo o costume, saíram antes do evento para "arregimentar" transeuntes como convidados da festa nos quarteiróes da Avenida Paulista e da Rua Augusta (Sentido Jardins). Com flyers nas mãos, convidaram a todos, predominantemente jovens, galerinhas, pessoas que saíam do trabalho, grupos sentados nas esquinas. A música estava alta e o templo não estava lotado, como ocorre nas demais festas, pois era gratuita e sem grande publicidade entre as igrejas evangélicas e templos da Sara no Estado. Jovens que não frequentam a igreja evangélica adentraram na balada; alguns perguntaram se era necessário pagar ingresso, entraram e dançaram junto com todos, outros somente entraram, conferiram o que acontecia e em seguida saíram. Durante a festa, duas jovens dançando juntas se abraçaram e se beijaram na boca. Os jovens líderes "ficaram de cara", todos continuaram dançando, mas olhavam uns para os outros sem saberem muito bem o que fazer; riam de forma contida, não por preconceito contra as meninas, mas de susto, surpresa, por não esperar a ocorrência de um "beijo gay" no interior do estabelecimento da "Igreja do Senhor". Ninguém fez o movimento de apartá-las ou informá-las de que, naquele exato momento, o programa institucional de socialização da igreja refuta o exercício do sexo e o erotismo entre pessoas do mesmo sexo. Até mesmo o pastor olhara com o mesmo sorriso de susto que os demais jovens. Passados alguns minutos, ele foi ao palco e falou sobre sua conversão. Disse que antes não acreditava em Deus e que gostava muito de determinado estilo de música. Todavia, aprendera por meio de sua experiência de fé em Deus, ainda na juventude, que "Ele é o maior amor que a pessoa pode ter na vida”. Falou sobre o sacrifício de Jesus na cruz como um ato de amor e chamou à frente os jovens que 
ELIAS EVANGELISTA GOMES. SINAIS DOS TEMPOS; SINAIS DOS LUGARES...

queriam "aceitar a Jesus". Tentou passar uma mensagem evangelística e, ao mesmo tempo, criar uma aproximação com eles, mostrando que algumas das disposiçôes de seu estilo de vida, a música e o vestuário, pareciam com as deles, afirmando, contudo, que essas e as demais eram orquestradas por sua fé em Deus.

A igreja etnografada possui um agendamento da sexualidade juvenil hegemônico no universo das igrejas evangélicas brasileiras, compreendido no seguinte marco regulatório: exercício do sexo pós-nupcial apenas entre duas pessoas de gosto sexual por sexos opostos. ${ }^{8}$ Trata-se de um programa institucional para a socialização dos fiéis composto por uma série de interdiçôes de caráter temporal e de orientação, abrangendo todos os sujeitos, independentemente de sexo, idade, histórico sexual e religioso. ${ }^{9}$ Interdiçóes como relacionamentos sem perspectivas de casamento (ficar), acesso à pornografia, à masturbação e a outras práticas que possam levar o jovem à iniciação sexual pré-nupcial ou ampliar os referenciais sobre gostos sexuais relacionam-se ao aspecto temporal. A interdição de orientação refere-se à oposição ao gosto pelo mesmo sexo. No programa, o sujeito dissidente sexual é aquele que se "desvia" do agendamento na sequência de eventos afetivos (orar, namorar, noivar e casar) e/ou no tipo de relacionamento e parceiro (entre pessoas de sexos opostos). Assim, na igreja pesquisada, as estratégias de socialização para sexualidade são constituídas a partir da dialética de tendências socializadoras de caráter geracional, demoninacional e espacial.

Contudo, a igreja insere-se em um espírito de época no qual o diálogo entre diferentes geraçóes ou autoridades é tido como prática mais eficaz para as prentensas transmissóes de valores do que os simples enunciados proibitivos. Regina Novaes (2001: 198) aponta que "alguns dizem que estamos vivendo um tempo de 'liberdade outorgada' pelos pais, o que até neutralizaria a rebeldia dos filhos. Mas, na verdade, os lugares 
REVISTA DE ANTROPOLOGIA, SÃO PAULO, USP, $20 \mathrm{I}$, V. 58 N $\mathrm{N}^{\mathrm{O}} \mathrm{I}$.

dos conflitos geracionais passam a ser outros". Os sujeitos têm solicitado um processo mais reflexivo (Giddens, 1991) e, assim, a argumentação faz parte do protocolo da socialização contemporânea: desejam saber mais do que apenas os enunciados dos princípios, ambicionam o conhecimento dos "porquês" e dos detalhes das interdiçôes postas no quadro geral de condutas.

A igreja pesquisada busca não proibir proibindo ou reprimindo de antemão as dissidências sexuais. Por meio de um processo continuado e compartilhado, visa fornecer um estoque de esquemas de ação baseados na fé e argumentos de impacto social (gravidez, doenças, não procriação de filhos entre pessoas do mesmo sexo, sofrimentos psíquicos) que balizem as vivências dos jovens. Esse processo continuado é resultado da percepção da igreja de que as experiências sociais dissidentes na juventude são provisórias e reversíveis, condicionamentos socialmente construídos e passíveis de revisão com mais facilidade do que entre os adultos detentores de categorias de julgamento mais bem delineadas.

Caderno de campo: Hoje teve a Parada do Orgulho LGBT de São Paulo. Até chegar à igreja, pulei algumas pessoas que estavam caídas e bêbadas no chão. Não acompanhei a festa, apenas os efeitos colaterais dela. Uma pessoa havia vomitado na porta do templo. Alguns jovens tinham vendido água na Parada com o objetivo de arrecadar fundos para uma viagem. Junto com um jovem líder e seu discípulo, fui a um fast-food. Durante algumas falas de animação de um jovem líder para que o discípulo se tornasse também um líder, entravam algumas pessoas fantasiadas, meninos (em especial) de mãos dadas. O jovem líder estava estranhando o clima da lanchonete. Até que resolveu expressar alguma posição a respeito do que via: "Eu fico com uma dó, são pessoas como nós, criadas por Deus também. Sabe o que faz uma pessoa ficar assim? É a falta de amor dos pais". Então, indaguei ao jovem: "Será que tem milhóes de pessoas mal amadas, hoje, na Avenida 
ELIAS EVANGELISTA GOMES. SINAIS DOS TEMPOS; SINAIS DOS LUGARES...

Paulista? Será que é isso?”. Ele respondeu: “Ninguém nasce assim. As pessoas se tornam assim. E é o amor de Deus que pode reverter".

A segunda chave de compreensão da igreja acerca da dissidência de gosto sexual teria um viés denominacional. $\mathrm{Na}$ igreja, mensagens como "terminar bem é mais importante do que começar bem" (Bispo Robson Rodovalho) revelam um discurso psicologizante, veículo de moralização crescente na esfera religiosa brasileira (Duarte, 2005). Segundo Alexandre Brasil Carvalho da Fonseca (1998), a leitura de livros com recortes psicológicos entre evangélicos de camadas médias, como no caso da igreja pesquisada, tem como objetivo a busca de respostas para os problemas cotidianos na combinação de fé e razão. Rubem Amorese (1995: 88), um autor evangélico incomodado com esse cenário, acusa haver uma "Lair-Ribeirização da fé", uma psicologia aplicada e pragmática que sustenta a teologia da prosperidade (Mariano, 1999), modo de conceber a vida cristã a partir da busca por viver aqui na terra "as riquezas", todos os tipos de bens que antes estavam limitados "à ida para o céu". ${ }^{10}$

Assim, a Sara Nossa Terra atrai o jovem com a mensagem de que ele pode ser "líder" na esfera financeira, profissional, familiar, escolar etc., não importando a condição de sua chegada à igreja, mas sim o ponto final de seu percurso. Reafirma-se o lugar das trocas simbólicas, do circuito de dádivas (Mauss, 2003) entre fiéis, pastores e Deus, envolvendo o perdão: reconhecer o pecado, confessá-lo, pedir perdão por ter rompido o sistema de trocas simbólicas entre Deus e a pessoa e receber o perdão, retribuindo com "uma vida de acordo com os princípios de Deus".

Essa mensagem "toca" de modo significativo os jovens de todos os gostos sexuais encontrados na igreja. A Sara Nossa Terra localiza-se no interior do campo religioso brasileiro, onde ocorre uma intensa disputa por fiéis (Mariano, 1999). Por isso, a combinação "fé com razão" na composição do estilo de vida cristão atrairia um público oriundo da 
REVISTA DE ANTROPOLOGIA, SÃO PAULO, USP, $20 \mathrm{I}$, V. 58 N $\mathrm{N}^{\mathrm{O}} \mathrm{I}$.

classe média, contribuindo para sua distinção - no sentido bourdieusiano - denominacional no campo evangélico, especialmente em relação ao neopentecostalismo rústico mais atraente aos pobres e vinculado às práticas mágicas, como no caso da igreja que pesquisei em Belo Horizonte. ${ }^{11}$

Essa demoniminação evangélica aposta no jovem como o principal porta-voz de sua mensagem evangelizadora. Sua organização interna ocorre por meio da Visão G12. O G12, grupo que reúne 12 pessoas para estudos e atividades eclesiais, é um sistema organizacional de multiplicação de fiéis importado das igrejas sul-coreanas e colombianas. ${ }^{12}$ Busca-se "ganhar São Paulo para o Senhor Jesus" numa progressão geométrica: 12, 144, 1.728 fiéis. Para esse fim, mobilizam-se prioritariamente os jovens, para que sejam líderes e cumpram funçôes pastorais de ensino da visão da igreja a outras pessoas. Além disso, é oferecida uma agenda extensa de eventos, festas, cultos e passeios, que visa conquistar mais fiéis e, principalmente, afirmar um estilo de vida no qual "ser evangélico não significa ser careta", como ouvi repetidas vezes na fala de jovens e pastores. Por meio dessa sociabilidade outorgada pela igreja, busca-se atrair os jovens para o templo e socializá-los na visão da igreja. É por meio desses grupos que tensões diversas vividas pelos sujeitos são encaminhadas para os cuidados eclesiais, sendo que os casos de relacionamentos afetivos e experiências sexuais possuem volume significativo de demanda.

A Sara Nossa Terra, além de compreender as dissidências a partir dos vieses geracional e denominacional, desenvolve estratégias de caráter espacial para a luta simbólica (Bourdieu, 1996) contra os gostos sexuais pelo mesmo sexo. No período do trabalho de campo, o duelo "mais agressivo" ocorria estrategicamente no Congresso Nacional, por exemplo, por meio da intervençáo do então Deputado Federal Robson Rodovalho, bispo-presidente nacional da igreja e membro das Frentes Parlamentares Evangélica e da Família e Apoio à Vida, resistindo à aprovação de leis e açóes governamentais para ampliaçáo dos direitos humanos e 
ELIAS EVANGELISTA GOMES. SINAIS DOS TEMPOS; SINAIS DOS LUGARES...

sexuais. Na audiência pública "Vida e Família num Ambiente Saudável", realizada em 2007 em Brasília, a posiçáo oficial do bispo-presidente da Sara é um dado interessante para a observação. ${ }^{13}$

Dep. Fed. Bispo Rodovalho: A natureza revela a glória de Deus. Então, a família é formada por um homem e por uma mulher. Não tem jeito de nascer um filho de dois homens ou duas mulheres. [...] Estude todas as distorçóes das grandes personalidades que foram assassinos ou psicopatas, eles tiveram grandes problemas na sua família. Todos eles trazem traumas familiares. [...] Sem família, esquece a sociedade, nós vamos ter uma barbárie convivendo em meio a uma tecnologia extremamente desenvolvida e toda a tecnologia que nós tivermos será usada para o mal. Não para preservar a vida, mas para destruir a vida e levar o homem a viver debaixo dos seus instintos.

Marcelo Natividade e Leandro Oliveira (2004) apontam que, no Brasil, observa-se uma "explosão discursiva" (Foucault, 1988) e intervencionista acerca da sexualidade na literatura, na mídia, nos templos e entre os parlamentares de filiação evangélica. Esses sujeitos chamam para si a legitimidade de serem portadores e "porta-vozes de valores universais, bastióes da moralidade, conjugando percepçóes negativas da diversidade sexual a uma atuação em oposição ao seu reconhecimento, compreendido como ameaça”" (Natividade e Oliveira, 2009: 132).

Esses autores destacam, ainda, a existência de um construtivismo moral evangélico, traduzido em modos de pensar e falar sobre a sexualidade e composto por três tendências: uma primeira, que considera o desejo sexual pelo mesmo sexo como uma manifestação espiritual demoníaca; uma segunda, notadamente psicologizante, que julga esse fato social como decorrência da experiência social do sujeito em famílias desestruturadas, o que implica um percurso antinatural; e uma terceira, 
REVISTA DE ANTROPOLOGIA, SÃO PAULO, USP, $20 \mathrm{I} 5$, V. $58 \mathrm{~N}^{\mathrm{O}} \mathrm{I}$.

que, reportando-se à noção liberal de comportamento responsável na sexualidade, desfoca a problematizaçáo da homossexualidade.

Segundo Natividade (2006), esse posicionamento construtivista entre os evangélicos tem como meta gerenciar os corpos na vivência de uma sexualidade dentro dos marcos regulatórios da doutrina eclesial. Nos dados apresentados aqui, observa-se que a Sara Nossa Terra localiza-se, sobretudo, naquela segunda vertente do construtivismo moral, o que não quer dizer que nos demais templos da denominação não possam aparecer outros posicionamentos. Institucionalmente, a Sara Nossa Terra busca conceber a dissidência a partir de um naturalismo com feiçóes próprias; nos termos de Natividade (2006: 122), "um essencialismo moldado culturalmente pela religião, submetido às concepçóes cosmológicas e doutrinárias" e, por sua vez, à concepção de que "a natureza que se fala é a natureza divina”.

No Congresso Nacional, o bispo-deputado alega com muita contundência que "a célula (família) está sendo destruída" pelos gostos dissidentes, "guerreia" e "batalha" como Davi contra Golias para mobilizar mentes e coraçóes para seu pânico moral e para que todos os evangélicos se unam sob a mesma bandeira do medo coletivo no encontro político com a diversidade sexual. ${ }^{14}$ Contudo, trata-se de um modo específico de uma luta simbólica contra os gostos que póem em risco o agendamento da sexualidade da igreja.

No templo pesquisado, longe da agressividade do ambiente parlamentar, observei uma estratégia institucional de 'acolher para transformar' os sujeitos que vivenciam gostos sexuais dissidentes, na qual persiste a noção da prática da homossexualidade como pecado. ${ }^{15}$ Predomina a psicologizaçáo, característica do alto pentecostalismo, aplicada à sexualidade para explicar a origem, a antinormalidade e as disfunçóes psíquicas dos sujeitos portadores de gostos sexuais dissidentes, o que pode ser observado nas falas tanto do bispo em Brasília quanto do jovem no dia da 
ELIAS EVANGELISTA GOMES. SINAIS DOS TEMPOS; SINAIS DOS LUGARES...

Parada do Orgulho LGBT. Entretanto, a estratégia de combate ideológico e espiritual à dissidência possui peculiaridades no universo do templo. ${ }^{16}$

O sujeito dissidente é bem-vindo à igreja e busca-se oferecer condiçóes para que ele possa se inserir "nos planos de Deus" de acordo com o tempo e a intensidade de sua imersão no circuito de cuidado da sexualidade. ${ }^{17} \mathrm{Ou}$ seja, inserir-se num sistema de trocas simbólicas, no sentido maussiano, envolvendo vários tipos de trocas entre os sujeitos da socializaçáo (fiéis, igreja e Deus) a partir de alguns elementos da cosmologia evangélica: conversão ("aceitar Jesus"), negaçáo do passado ("largar tudo"), adequação aos princípios da igreja ("seguir os caminhos do Senhor"), entre outros.

No tocante à juventude, compreende-se que os jovens vivam um momento de transitoriedade, estando mais propensos à reversibilidade (Pais, 1993) de gostos e experiências e, ao mesmo tempo, não se sujeitando facilmente às prescriçôes meramente proibitivas. Por isso, 'não proibir proibindo' e não acusar de antemão os sujeitos que vivenciam gostos dissidentes é uma forma de "dar tempo ao tempo", de 'acolher para transformar'. Seguindo a lógica da igreja, se ela considerasse que a dissidência de gosto fosse uma manifestação unilateralmente demoníaca, necessitar-se-ia uma intervenção mais rápida, por exemplo, em relação às duas meninas que se beijaram na mencionada festa dentro do templo. Por isso, o silêncio estratégico em relação ao "beijo gay" torna-se importante para que elas e os demais jovens de gostos sexuais pelo mesmo sexo se "sintam bem na igreja e possam voltar".

Menino (01): Você viu aquele dia, as meninas se beijaram. Imagina que se alguém tivesse chegado lá: "Ouououou... Vamos dispersar, vamos dispersar...”. Seria o fim, jamais voltariam à igreja. Tem que ganhar primeiro, para depois consolidar, discipular e por aí vai. A tarefa do líder é ter paciência. É assim: paixão, dedicação, paciência e maturidade. Tem que plantar a semente. 
REVISTA DE ANTROPOLOGIA, SÃO PAULO, USP, $20 \mathrm{I} 5$, V. 58 No I.

A socialização para adesão ao agendamento da sexualidade na igreja pesquisada ocorre num espaço privado, denominado de discipulado individual, no qual o jovem líder ensina, ouve confissóes e cria estratégias de resolução de problemas vividos por outros jovens, como já fora mostrado também por Natividade (2003) em seu estudo sobre carreiras homossexuais entre pentecostais no Rio de Janeiro. Na igreja em questáo, a abordagem privada da sexualidade ocorre para todos os gostos sexuais, sendo que a adesão a esse modelo não se distribui de modo homogêneo entre os fiéis. ${ }^{18}$ Em tais espaços, não se expóe de imediato aos jovens novos na igreja o que "não é permitido" ou o que é definido como "carne", na polarização cosmológica entre "espírito" e "carne" referente ao agendamento da sexualidade. Náo se pergunta antecipadamente se a pessoa é "gay" ou "lésbica", mas espera-se que ela mesma "se abra" ao seu líder, de forma que possa "receber os cuidados", ou seja, os ensinamentos bíblicos, a reafirmação do agendamento da sexualidade e a aplicação de estratégias para que esteja apta a "largar tudo para seguir Jesus".

De alguma forma, aposta-se no fato de que a pessoa náo procura a igreja aleatoriamente, mas porque está também interessada em se inserir (mesmo que parcialmente) no universo simbólico da igreja, como lembrado por Bourdieu (2002), para quem a parceria do dominado é necessária em qualquer sistema de dominação. Nas festas, nos cultos e nas atividades de pequenos grupos, busca-se estimular a aproximação e a familiarização entre sujeitos ("tornar-se amigos"), favorecendo a criação de um ambiente de confiança para "consolidar" o jovem na igreja, de modo que, com o tempo, ele possa reconhecer em si mesmo aquilo que é pecado, bem como perceber a necessidade de relatar suas experiências dissidentes e receber os cuidados de seus socializadores. ${ }^{19}$

Ter um grupo de amigos, sentir-se acolhido e ter um lazer na cidade são fatores que funcionam como pontos de partida para que o jovem dissidente possa se inserir num circuito de cuidado, de trocas simbólicas 
ELIAS EVANGELISTA GOMES. SINAIS DOS TEMPOS; SINAIS DOS LUGARES...

em torno da sexualidade. As práticas socializadoras para adesão ao agendamento da sexualidade preservado pela igreja baseiam-se em processos comunicativos, iniciados no lazer, nas festas e nos cultos, e intensificados em um ambiente de confiança, cujo mediador inicial é o jovem líder do G12. No âmbito dos gostos pelo mesmo sexo, os mediadores da socialização dos dissidentes são jovens heterossexuais que têm segurança de gosto. ${ }^{20}$ Por vezes, eles passam aos adultos e pastores a tarefa de cuidar dos jovens de gostos dissidentes. No cuidado autônomo, esses jovens heterossexuais precisam treinar, elaborar e colocar em prática seus modos de julgar, hierarquizar gostos, práticas e sujeitos. Precisam recorrer às suas experiências para criar aproximação e diálogo.

Pesquisador: Mas o que você falou para ele [discípulo que tem "questóes gays"]?

Menino (02): Entáo, eu disse para ele se afastar daquilo que fazia ele pensar em outro menino, tipo ir às baladas que tem gays, ficar muito tempo na internet; para vir mais na igreja, que as festas da Sara são boas, tem gente bonita, bons DJ's. Disse para ele procurar o pastor, que ele ia ajudá-lo. Orar para que a família dele se rendesse aos pés do Senhor, os amigos também. Falei para ele relaxar que Deus ia fazer a obra [a reconversão de gosto] na vida dele. Eu dei vários exemplos meus, do que eu consegui superar, para ele ver que também era possível. ${ }^{21}$

Nesse encontro com os gostos sexuais dissidentes na igreja, os jovens heterossexuais, na socialização de seus discípulos, precisam negociar os princípios de exclusividade de gosto, as estratégias de 'psicologizar', de 'acolher para transformar', de 'não proibir proibindo' e de "dar tempo ao tempo", bem como compreensóes resultantes do conjunto de experiências significativas de sua socialização na família, na escola, na mídia, entre amigos e no espaço urbano. Tal encontro pode provocar um 
REVISTA DE ANTROPOLOGIA, SÃO PAULO, USP, $20 \mathrm{I} 5$, V. $58 \mathrm{~N}^{\mathrm{O}} \mathrm{I}$.

impacto "tremendo" em suas categorias de percepçáo. Por exemplo, um jovem vindo de uma igreja de neopentecostalismo rústico ou de pentecostalismo tradicional não poderá acusar as meninas do "beijo gay" de estarem endemoniadas; ao contrário, a situação lhe impóe a necessidade de reconfigurar suas categorias de compreensão da fé e da dissidência de gostos pelo mesmo sexo, demandando-lhe atribuir significados psicologizantes às dissidências, bem como uma nova postura na recepção dos dissidentes na igreja. Não menos interessante é compreender o sorriso no caso do "beijo gay", pois ora revela uma "paciência" estratégica com os tempos individuais para que num futuro próximo se possa "ganhar a pessoa para Jesus", ora revela um susto (estranhamento) ao encontrar um 'outro' que "só se conhecia de ouvir falar, mas agora se vê", pois não está fora, nem perto, nem ao lado, mas dentro da igreja.

\section{O encontro com a homossexualidade na rua}

Caderno de campo: Ao terminar o culto, (nome suprimido), um jovem líder, chamou seus discípulos para uma "noite especial" de convivência, que o tempo todo e a cada momento foi ressaltada como declaração de carinho e amizade para com eles. Tratava-se de uma modalidade do que se denomina "discipulado coletivo". Andamos pela região da Avenida Paulista. Fomos a uma lanchonete próxima à Rua da Consolação, mas os jovens acharam caro o valor da alimentação e prosseguimos na andança. Depois de, um por um, pularem caixas empilhadas na calçada, escorregarem nos corrimãos de uma agência bancária, atravessarem a rua correndo antes que o sinal abrisse, fazerem pose para fotos, decidiram ir ao carrinho de lanches na Rua Frei Caneca com a Avenida Paulista, via pública conhecida como "a rua mais gay da cidade" pelo volume de estabelecimentos de lazer frequentados pela comunidade LGBT da capital e turistas. O lanche 
ELIAS EVANGELISTA GOMES. SINAIS DOS TEMPOS; SINAIS DOS LUGARES...

era uma "desculpa" (termo usado inúmeras vezes por socializadores para explicar esse processo) para o jovem socializador ensinar princípios cristãos e falar sobre a importância da evangelização para "ganhar São Paulo para o Senhor Jesus". O grupo era formado por três meninos de gostos sexuais pelo mesmo sexo (mas só um era da igreja, os outros eram seus amigos), por três meninos de gosto pelo sexo oposto, por um que já se relacionou sexualmente com meninos, mas não se relaciona mais (atualmente é "hétero"), pelo líder que estava em vias de se casar com uma jovem da igreja e por uma menina da qual não tenho informaçôes sobre a sexualidade e que, teoricamente, não era para estar com o grupo dada a divisão de gênero para o discipulado individual e coletivo ("meninos com meninos" e "meninas com meninas"), mas que desejava acompanhar seus amigos (os "gays"). Até aí, o grupo de jovens interagia sem demarcaçôes explícitas de gostos sexuais. Todos dedicavam o mesmo tratamento aos outros. Conversavam e bricavam. A madrugada já tinha começado e, depois de lancharmos, descemos a pé a Rua Frei Caneca em direção ao centro antigo da cidade, próximo à regiáo da igreja. Passamos em frente e próximos aos sujeitos e estabelecimentos "gays" (bar, sauna, shopping, balada, clube de sexo). No grupo, eu tinha três informantes privilegiados, o líder (hétero) e dois discípulos, um "gay” e um "hétero". O líder dispensava atenção aos jovens na persistência de ensiná-los condutas cristấs gerais (trabalho, família, amor etc.). Os dois outros informantes eram moradores da região central, porém, naquela situaçáo, mantinham relaçóes com o ambiente opostas às observadas em outras circulaçóes na região. O "gay" que, anteriormente, circulara comigo na região me apresentando os estabelecimentos GLS e contando suas histórias de vida de dissidência sexual, "mantinha a linha" contida e nada comentava sobre as referências sexuais da rua. Seus amigos "gays", por sua vez, tentavam se integrar ao universo simbólico evangélico, faziam comentários sobre o culto, cantavam músicas e contavam suas experiências em igrejas evangélicas, sem fazer menção aos seus gostos sexuais. 
REVISTA DE ANTROPOLOGIA, SÃO PAULO, USP, $20 \mathrm{I}$, V. 58 N $\mathrm{N}^{\mathrm{O}} \mathrm{I}$.

Os "héteros", por sua vez, "se jogaram" no ambiente, estavam completamente animados. Brincavam, se empurravam, pulavam uns nos outros, se estapeavam, muito mais agitados do que os demais. A menina, mais próxima dos "gays", interagia com os dois grupos. Andando juntos, os familiarizados com a região faziam questão de manter certo distanciamento em relação à ela, enquanto os estranhos pareciam muito mais familiarizados.

A Rua Augusta, onde se localiza a Comunidade Evangélica Sara Nossa Terra, é frequentada por turistas brasileiros e estrangeiros e por certa população de camada média da cidade, todos interessados nos estabelecimentos de lazer que estáo ali instalados (bares, cinemas, museus, feiras, lojas, livrarias, dentre outros). O fluxo de pessoas e de interesses nessa regiáo não é homogêneo, havendo a concentração de grupos em determinados quarteirôes e a formação de manchas e circuitos de lazer (Magnani, 2005). A Rua Augusta pode ser observada em pelo menos duas partes. Essa divisão ocorre precisamente no cruzamento com a Avenida Paulista, via nacionalmente conhecida devido aos eventos políticos e culturais que ali acontecem, tais como a Parada do Orgulho LGBT e a Virada do Ano Novo.

O Trecho 01 da Rua Augusta, que sai do centro da cidade e chega à Avenida Paulista, incluindo suas adjacências, possui grande número de bares, restaurantes, padarias, casas de shows, cabarés e prostíbulos. O Trecho 02, que se localiza entre a Avenida Paulista e meados de uma das regióes mais nobres da cidade - o bairro Jardins e suas adjacências -, conta com bares e restaurantes mais caros e sofisticados, lojas de marcas da moda internacional e apartamentos de luxo. O templo investigado está no Trecho 02 e se situa a dois quarteiróes da Avenida Paulista. Por isso, passam em frente a ele pessoas que circulam prioritariamente no Trecho 01 e que vão a um cinema e a um bar instalados nas laterais do templo evangélico. Entre esses transeuntes estáo muitas pessoas de gosto 
ELIAS EVANGELISTA GOMES. SINAIS DOS TEMPOS; SINAIS DOS LUGARES...

sexual pelo mesmo sexo, a maioria das quais não se interessa pela igreja e, como observei em diversas ocasióes, faz comentários jocosos contra a igreja e os jovens que a frequentam, como se fosse uma resposta à resistência das igrejas evangélicas aos seus gostos e estilos de vida.

Ronaldo de Almeida (2004) aponta que a distribuiçáo espacial de templos das igrejas evangélicas na cidade de Sáo Paulo pode ocorrer de acordo com um perfil de sociabilidade e gestão administrativa da denominação. ${ }^{22}$ Nessa direção, os interesses da Sara Nossa Terra parecem se cruzar com o perfil da rua, pois a denominação se interessa (não só, mas original e principalmente) por um público de classe média, empresários e jovens, o que a faria expressar um estilo de vida moderno (não "careta") que a diferenciaria de outras denominaçóes evangélicas.

Caderno de campo: Ontem à noite, andei na Rua Augusta, da igreja até o centro da cidade, junto com um jovem de gosto pelo mesmo sexo que frequenta a Sara. Ele contava a sua experiência sexual fazendo inúmeras alusóes aos estabelecimentos que estáo naquela região. Explicou que entendia a rua da seguinte maneira: Trecho 01 = inferno; Trecho 02 = céu. $\mathrm{O}$ inferno era representado pelos bares, prostíbulos e baladas; o céu, pela nobreza e riqueza visíveis nos restaurantes mais caros e frequentados por pessoas com maior poder aquisitivo. Essa mesma noção está presente também na fala de uma jovem estilista náo evangélica que foi ao templo, meses atrás, vestir os jovens para um desfile que aconteceu numa das festas. Segundo ela: "A (Rua) Augusta vai do luxo ao lixo". Em um sábado anterior, levei minha namorada à Rua Vieira de Carvalho para conhecer outro "território gay” de São Paulo, mais popular. Por volta da meia noite, eis que passa por nós esse mesmo jovem acompanhado de um "amigo". Informou-me que tinha ido ao culto e que, naquele momento, estava "passeando um pouco". Seguindo sua lógica, na mesma noite ia do céu ao inferno; em outras ocasióes, declarava ter feito movimentos contrários (à tarde, dissidências e, à noite, culto). 
REVISTA DE ANTROPOLOGIA, SÃO PAULO, USP, $20 \mathrm{I}$, V. $58 \mathrm{~N}^{\mathrm{O}} \mathrm{I}$.

\section{Centro Velho}
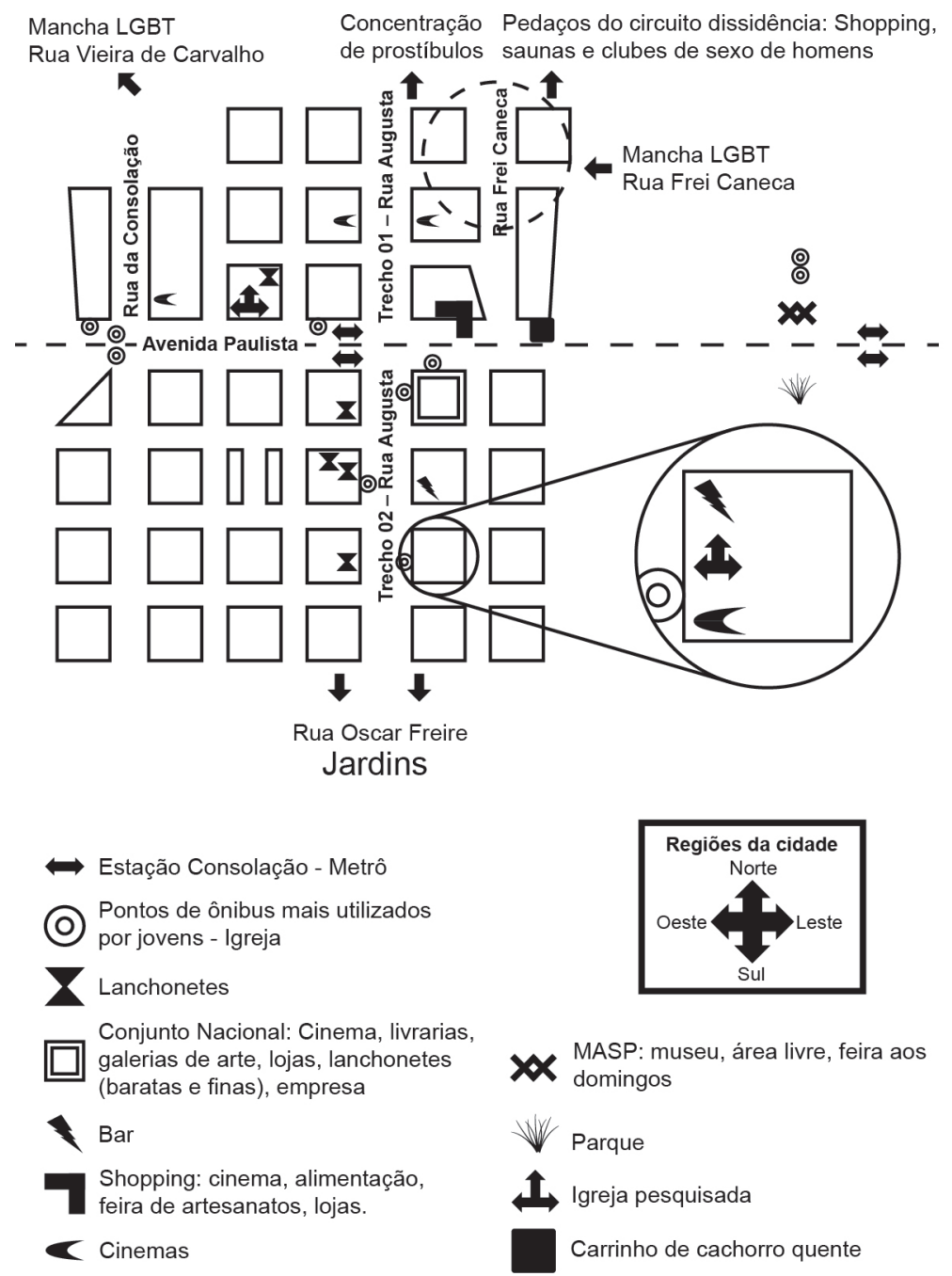

Mapa: Região da Rua Augusta (Cidade de São Paulo - SP - Brasil. Autoria: Elias Evangelista Gomes) 
ELIAS EVANGELISTA GOMES. SINAIS DOS TEMPOS; SINAIS DOS LUGARES...

Nesses termos, a igreja estaria no polo céu, combinando tanto suas perspectivas evangelizadoras de "levar mais pessoas para o céu", como seu intento de se aproximar de um público que circula no céu urbano: a classe média. Contudo, ao contrário dos adultos da igreja, em sua maioria de classe média e média alta, os jovens, majoritariamente, são de classe média baixa, oriundos da periferia da cidade, de bairros que, por vezes, estão a uma hora e meia de distância do templo. ${ }^{23}$

Menino (03): Quando eu fui à Sara Augusta pela primeira vez, eu fiquei assustado. Vi um cara beijando outro na rua. Lá no meu bairro, eu nunca vi isso. Achei muito estranho, mas estão na rua. Mas o legal é que na Sara não tem preconceito. Ela recebe bem os homossexuais, se você perceber tem alguns que frequentam a igreja. Ela não aceita a prática, mas cada um tem seu tempo para entender as coisas.

Mãe do menino (03): A igreja lá é fina, né? Tem gente muito sofisticada lá. Quando o (nome suprimido) começou a ir lá, eu achei ruim com ele, porque a gente ouve falar muito mal da (Rua) Augusta. Tem prostituição, gay, tudo mais. Mas vi que lá ele estava seguro. Eu falo para a meninada daqui da rua ir lá, mas acho que eles não querem nada com Deus, não. Gostam mesmo é de ficar aqui na esquina.

Pude ir às casas de alguns jovens e observar que as polarizaçóes entre Trecho 01 e Trecho 02 da Rua Augusta colocavam-se de forma semelhante em relação ao centro e ao bairro. Os jovens eram prestigiados pela família e pelos amigos por frequentarem uma igreja "sofisticada", transformados em outsiders num lar/bairro de estabelecidos (Elias e Scotson, 2000). $\mathrm{O}$ percurso do bairro ao centro (Rua Augusta) náo é tranquilo, pois alguns pais e algumas mães estranham o fato de seus filhos passarem a madrugada na rua ou mesmo de circularem em espaços de sociabilidade 
REVISTA DE ANTROPOLOGIA, SÃO PAULO, USP, $20 \mathrm{I} 5$, V. 58 No I.

GLS, fazendo com que os jovens tenham que desconstruir preconceitos em relação à rua no interior de suas próprias casas para que a circulação seja concedida e menos tensionada. Alguns deles, por exemplo, ocultam a circulaçáo no Trecho 01, transmitindo a ideia de que circulam apenas no céu da cidade e da Rua Augusta. ${ }^{24}$

Os estranhamentos com os gostos pelos mesmos sexos (beijos, carícias, vestimentas e sociabilidade) na rua devem chegar em casa com certa neutralidade para que o próprio percurso na cidade não seja objeto de estranhamento na família. Assim, em casa, os jovens de gosto pelo sexo oposto precisam lançar mão de argumentos que lhes confiram certo distanciamento da dissidência. Busca-se evidenciar para a família certa segurança não apenas em relação à violência da grande metrópole, mas também uma segurança de gosto, em que o fato de ir a uma "igreja que tem gays" e de andar numa "rua que tem gays" não o tornará "gay" nem o fará reconfigurar seu gosto sexual. Para que o lazer seja outorgado pela família, dispóe-se de certo instrumental construtivista moral da sexualidade (Natividade e Oliveira, 2004, 2009). Em outras palavras, os sentidos do jogo são conhecidos (Bourdieu, 1996) e a argumentação psicologizante sobre homossexualidade é utilizada para viabilização da mobilidade urbana e do trânsito religioso.

\section{Conversa no MSN:}

Pesquisador: Mas seus colegas ficavam falando que tinha muito gay na Augusta...

Menino (04): É. Mas não tem nada não. Deus ama todo mundo. Os caras (gays) estão é no caminho errado. Só isso.

Pesquisador: Mas, lance de demônio, essas coisas?

Menino: Só lá na minha igreja antiga, lá na Sara não tem isso. Você acha que se eu pensasse que os caras têm espírito eu andaria lá? Nem passava perto. Estava longe. 
ELIAS EVANGELISTA GOMES. SINAIS DOS TEMPOS; SINAIS DOS LUGARES...

É menos impactante circular em um espaço em que há pessoas com problemas psíquicos e construçôes inadequadas da sexualidade do que em um ambiente espiritual demoníaco. Nesse aspecto, a cosmologia evangélica da prosperidade que psicologiza a experiência de fé e as dissidências sexuais contribui para que a circulaçáo nos Trechos 01 e 02 e até mesmo a frequência à Parada do Orgulho LGBT para ficar com meninas sejam vividas com menos "culpa" do que, por exemplo, a vivência em um espaço "carregado" por "espíritos maus". Um jovem, importante informante, em um lanche/entrevista, evidenciou que sentia certa tranquilidade ao ir à Parada para ficar com meninas, pois tinha segurança de gosto e pedia perdáo por ter ficado com as meninas ("Eu sei do que gosto e isso [ir à Parada] não vai me influenciar a parar de gostar de meninas"). Nesse caso, o jovem de gosto sexual pelo sexo oposto encontrava-se ao lado do dissidente para vivenciar sua própria dissidência em relação ao agendamento temporal da sexualidade proposto pela igreja e, ao mesmo tempo, afirmar sua adesão, sua convicção e certa naturalização de seu gosto sexual.

O encontro do jovem evangélico de gosto sexual pelo sexo oposto com os sujeitos de gosto pelo mesmo sexo na Rua Augusta estimula também aquela "explosão discursiva" (Foucault, 1988) sobre sexualidade. Encontrar-se com o 'outro' é um fenômeno no qual o jovem evangélico precisa pensar e negociar seus modos de conceber a fé e os gostos sexuais, tanto os seus quanto os dos demais sujeitos. A mobilidade espacial influi diretamente na formação das categorias de pensamento desses jovens que assumem ou não os princípios da igreja. $\mathrm{O}$ gosto sexual pelo mesmo sexo é considerado uma dupla dissidência (temporal e de orientação) a partir dos parâmetros eclesiais e é assimilado pela maior parte dos jovens. Porém, no encontro com o 'outro', durante a circulação na região da igreja, eles são provocados a pensar modos de se relacionar com os sujeitos e suas práticas dissidentes. São levados a construir modos de coexistência de visóes de mundo e gostos sexuais distintos no mesmo espaço urbano. 
REVISTA DE ANTROPOLOGIA, SÃO PAULO, USP, $20 \mathrm{I}$, V. 58 N $\mathrm{N}^{\mathrm{O}} \mathrm{I}$.

A espacialidade da Rua Augusta não é só disputada para evangelizar, mas para o lazer e a sociabilidade.

Assim, a dureza das palavras do bispo no Congresso Nacional já não aparece nas falas e formas de agir e julgar de muitos jovens da igreja, pois as noçóes desses acerca da rua vão além da evangelização. Como lugar de uso compartilhado para a fruiçáo urbana, a rua tem, em si, um sentido final. Em alguns casos, percebe-se um desfocamento da homossexualidade como o centro do olhar e da experiência de fé, passando o “estranho" a ser "familiar" (Velho, 2003).

Pesquisador: Você disse que mudou muito sua maneira de ver a homossexualidade. $\mathrm{O}$ que mudou?

Menino (05): Olha, mano, eu não vou ficar aí falando que não é de Deus, pois, você sabe, os caras e as minas ficam entre si porque querem, porque estão a fim. Mano, tem cara que você olha aí e vê. Aqueles dois que saíram daqui. Nossa! O cara ama o outro mesmo. Às vezes, fica só por ficar, mas na igreja também tem isso. Na minha casa aprendi que gay não é de Deus, na igreja também, a vida toda assim. Náo sei se estou errado, mas acho que se o gay quer vir para a igreja tem que vir, ninguém tem que ficar olhando para ele torto, nem sei se tem que ficar tentando converter o jeito dele ser. Quem sabe, é um direito dele. Eu não sei, acho tudo isso muito complicado, mas já mudei muito meu jeito de ver as coisas desde que vim aqui para a Sara. Eu era meio tapado, olhos vendados. Antes, achava mais esquisito, agora eu olho e vejo, estão ali e eu aqui na mesma lanchonete. Um dia, fiquei pensando: "será que se a pessoa aceitar a Jesus e ser gay vai para o céu?” Não conta para ninguém... É meio contraditório...

Pesquisador: Falou! Não vale censurar, não! Só vou publicar nos quatro cantos do mundo, mas eu tiro seu nome.

Menino: É meio contraditório... Estava pensando: "o cara vai para o céu, sim, pois ele aceitou a Jesus como salvador e senhor, a sexualidade é um 
ELIAS EVANGELISTA GOMES. SINAIS DOS TEMPOS; SINAIS DOS LUGARES...

mero detalhe". Imagina se eu fosse pirar com tudo que eu já fiz que a igreja diz que é errado, eu já tinha ficado louco. Se eu não quero ficar louco por isso, por que eu quero que aqueles caras fiquem? Entendeu? Estava pensando umas coisas assim. Mas, mano, eu não sei. Acho que Jesus quer todo mundo, só isso. O resto é resto.

Nesses aspectos, a própria espacialidade da rua é educativa, pois a visão fantasmagórica do homossexual como um 'outro' distante, que só existe nas piadas e interdiçôes bíblicas, dá lugar a um olhar "afetivo" sobre o sujeito, aquele que se quer "ganhar para Jesus" ou aquele que é "parceiro" na ocupação do mesmo espaço de lazer. Para alguns jovens, assim como para alguns etnógrafos, a "experiência afetiva" (Favret-Saada, 2005) torna-se objeto de análise para compreender a dissidência do outro. Nesse caso, o modo de julgar baseia-se não mais em um homossexual idealizado, mas em um sujeito que ama, tem carinho e é erotizado, "assim como eu". Contudo, essa dimensão afetiva de encontrar a homossexualidade pode ser repulsiva ("gay, não quero ver nem perto"), inclusiva/desfocalizadora ("Acho que Jesus quer todo mundo, só isso. O resto é resto"), acolhedora ("relaxa que Deus vai fazer a obra”) ou pragmática ("fui à Parada Gay sem problema"). ${ }^{25}$

Entre os meninos heterossexuais autodeclarados que encontrei em campo, há poucos casos de jovens que repulsam os sujeitos homossexuais de forma contundente. Os que atuam com essa corrente de pensamento, na maioria dos casos, são oriundos de igrejas pentecostais "rústicas" (Almeida Junior, 2008). Assim, no conjunto dos jovens heterossexuais com os quais conversei ao longo da pesquisa, há uma grande tendência a 'acolher para transformar' os homossexuais para que reconvertam seus gostos sexuais e uma minoria inclusiva/desfocalizadadora, constituída por aqueles que consideram as modalidades de dissidência de gosto como experiências sociais legítimas ou que náo são importantes para o "julgamento final”. 
REVISTA DE ANTROPOLOGIA, SÃO PAULO, USP, $20 \mathrm{I} 5$, V. 58 No I.

\section{Sinais finais}

Segundo Bernard Lahire (2006), os sujeitos convivem, desde crianças e cada vez mais, em um cenário social no qual se deparam com situaçóes heterogêneas, concorrentes e, às vezes, contraditórias em seus processos de socialização. A coerência de seus esquemas de ação dependeria, então, da coerência dos princípios de socializaçáo a que estáo submetidos. Contudo, nesse cenário social de pluralidade, seu estoque de esquemas de ação poderá não ser homogêneo e variar segundo o contexto social que serão levados a valorizar.

Etnografei um templo bastante peculiar pelo fato de se inserir em um espaço urbano no qual a homossexualidade está fora do armário. Observei que, entre os jovens meninos que gostam de meninas oriundos da periferia, os modos de pensar a homossexualidade estáo em processo de reconfiguração a partir do encontro com o 'outro' na igreja e na rua. O jovem que chega à igreja com posiçóes repulsivas aos sujeitos e suas práticas dissidentes é socializado pelos pastores e líderes na tentativa de que coloque sua repulsão aos sujeitos no armário, a fim de não atrapalhar a "meta" institucional de 'acolher para transformar' e de não parecer uma igreja "careta”. Na rua, os modos de pensar, 'espiritualizantes' ou 'psicologizantes', por vezes são colocados no armário para que a mobilidade na cidade possa conferir prestígio e abrigar suas próprias dissidências. Do mesmo modo, aquele jovem que passa a ter um olhar afetivo para os sujeitos e suas práticas dissidentes precisa manter seu novo modo de pensar no armário a fim de se manter unido à comunidade de fé e à compulsoriedade de gosto sexual. ${ }^{26}$ Nesses aspectos, todos esses jovens são atraídos a interpretar a homossexualidade - em suas dimensóes econômica, social, estética e religiosa - seletivamente de acordo com a configuração dos tempos e lugares, da fé e da rua.

$\mathrm{Na}$ busca por viver um estilo de vida contemporâneo, a igreja e os jovens encontram-se com a homossexualidade presente na rua num 
ELIAS EVANGELISTA GOMES. SINAIS DOS TEMPOS; SINAIS DOS LUGARES...

processo de familiarização e estranhamento, bem como de aproximação e distanciamento nada desinteressado. Assim, o modo como a Sara Nossa Terra cosmologiza (pensa) a fé e os gostos sexuais dissidentes pode ser sua própria cilada. Pelo que pude observar, muitos jovens são 'simpatizantes' da visão 'psicologizante', e aqueles que demonizam a homossexualidade acabam por aderir mais facilmente à visão de "acolhimento", assumindo certo declínio das explicaçôes mágicas sobre as dissidências sexuais. Pragmaticamente, não querem ser vistos circulando em um espaço urbano e "espiritualmente carregado" ou não planejam compreender suas próprias dissidências do ponto de vista espiritual, mas sim em uma perspectiva social e psicológica, o que causa menos "medo". Esta é a encruzilhada da igreja evangélica: ofertar ao fiel um novo esquema de ação que seja atrativo e que, contraditoriamente, retire-lhe autoridade na explicação das coisas via magia, como pudemos observar na fala de certo jovem, que diz: "Você acha que se eu pensasse que os caras têm espírito eu andaria lá? Nem passava perto. Estava longe".

Assim, o psicólogo e o cientista social são peritos (Giddens, 1991) que têm "alimentado" o campo religioso com seus múltiplos agentes e argumentos, sujeitos de áreas do conhecimento que têm mostrado que a fé também é construída socialmente. A Sara Nossa Terra da Rua Augusta tem colocado certa 'cosmologizaçáo espiritualizante' dos gostos sexuais e da fé no armário, na tentativa de atrair mentes e coraçóes ao seu programa institucional de socializaçáo. Ela sabe estrategicamente com quem, onde, como e quando lutar contra a homossexualidade. O jovem é seu principal alvo e porta-voz. Ela sabe dosar distintamente a agressividade da luta simbólica no parlamento e no templo, a fim de 'acolher para transformar'; ela "dá tempo ao tempo", "batalhando" para que as "reconversôes" das dissidências de gostos sexuais ocorram. Essa reconfiguração resulta da disputa por pessoas e fiéis num campo religioso de grande concorrência, tendo classe, etapa da vida e escolarizaçáo como 
REVISTA DE ANTROPOLOGIA, SÃO PAULO, USP, $20 \mathrm{I} 5$, V. $58 \mathrm{~N}^{\circ} \mathrm{I}$.

marcadores sociais e culturais de diferença orientadores de seu "foco". Concomitantemente, o templo localiza-se em um espaço urbano em que as categorias de pensamento sobre gostos sexuais também estáo em disputa, demandando novas formas de encontro entre sujeitos e suas práticas dissidentes.

Enquanto na igreja da periferia de Belo Horizonte, no seio dos conflitos com o tráfico de drogas e a violência, percebi um discurso mais 'espiritualizante' sobre as dissidências de gostos sexuais, no centro de São Paulo, no seio da classe média paulistana, observei um discurso mais 'psicologizante' e "acolhedor". Como os muros da cidade não estão bem delimitados, o ilícito convive com o lícito, o centro convive com os bairros, e os jovens da periferia estão lá na Rua Augusta reconfigurando seus modos de pensar as dissidências de gostos sexuais, o que pode chegar silenciosamente, mesmo que de forma tensa, a suas casas, bairros e novas igrejas que venham a frequentar.

A partir das análises de Louis Dumont $(1992,1997)$ sobre o individualismo, é possível observar, nas duas igrejas estudadas em minhas pesquisas (na periferia de Belo Horizonte e no centro de São Paulo), ao menos duas diferenças significativas no sistema de valores empregado para analisar a sexualidade: respectivamente, uma característica tradicional-holística, concebendo o social de modo hierárquico, e uma característica moderno-individualista, que o concebe sob a ótica do igualitarismo. Esses dois modos de conceber as dissidências de gosto sexual implicam processos de estranhamento e familiarização com as práticas e os sujeitos que não aderem ao agendamento da sexualidade proposto pela igreja evangélica. Os dois modelos de agenciamento do social podem explicar parcialmente o maior estranhamento de alguns jovens da periferia, oriundos de igrejas pentecostais clássicas, com os sujeitos dissidentes, ao mesmo tempo em que aqueles jovens que se aproximam mais da classe média estranham em menor grau a homossexualidade 
ELIAS EVANGELISTA GOMES. SINAIS DOS TEMPOS; SINAIS DOS LUGARES...

presente no interior da igreja e na Rua Augusta, por vezes recorrendo à noção de "direito" à vivência da livre expressão da sexualidade. ${ }^{27}$

O encontro entre gostos sexuais no cenário evangélico tem garantido novas formas de conflito. Não menos interessante é observar os conflitos religiosos em torno do direito de ter fé em Deus no campo religioso brasileiro, com a emergência de "igrejas inclusivas". Em meio às acusaçôes, o argumento 'espiritualizante' reaparece e sai do armário daquelas igrejas que o tinham guardado, na condenação de que os pastores dessas igrejas seriam "pastores do diabo" (Natividade, 2008). Segundo Fátima Weiss de Jesus (2010), a partir das disputas por legitimação do capital religioso, essas igrejas inclusivas estariam contribuindo para mudanças na visão tradicional sobre homossexualidade.

A observação antropológica acerca do histórico das lutas das minorias sociais no interior das igrejas evangélicas revela os sinais dos tempos. No Brasil, em 1960, qual pentecostal conseguiria imaginar a proliferação de mulheres pastoras, das calças, dos brincos e das maquiagens nos púlpitos? Ou quem vislumbraria uma igreja protestante histórica com guitarra e grupo de dança? Quem imaginaria igrejas inclusivas que pregariam o Evangelho interpretado sob a ótica da diversidade sexual? No caso das igrejas protestantes, as mudanças ocorreram, sobretudo, a partir da juventude. Segundo Regina Novaes (2006: 119), "a juventude é como um espelho retrovisor da sociedade", mas o jovem de hoje vive uma experiência social "inédita".

A Comunidade Evangélica Sara Nossa Terra da Rua Augusta pretende "sarar" os jovens de uma geraçáo que vive em um mundo mais veloz e interconectado, numa cidade em que o ilícito e o lícito têm se capilarizado nas tramas da vida social (Telles e Cabanes, 2006) e em que a sexualidade está muito mais politizada e visível, inclusive na igreja. Por essa razão, não é menos interessante pensar os sinais dos tempos e dos lugares a partir das óticas dos jovens, buscando não apenas compreender como os sujeitos de gosto sexual pelo mesmo sexo encontram-se com a 
REVISTA DE ANTROPOLOGIA, SÃO PAULO, USP, $20 \mathrm{I}$, V. 58 N $\mathrm{N}^{\mathrm{O}} \mathrm{I}$.

fé e com a igreja, mas também como jovens heterossexuais encontram-se com a diversidade sexual na rua e na igreja.

Nessa "explosão discursiva" sobre sexualidade no encontro desses jovens heterossexuais com a homossexualidade, emergem novas regras e novas formas de controle (Bozon, 2004) de si e do outro. Por isso, nas pesquisas sobre as cosmologias religiosas acerca da sexualidade, é preciso ter um olho na instância religiosa e outro no fiel, "um pé na igreja e o outro no mundo" (templo e rua). Em suma, no cotidiano dos jovens pesquisados, não existe fonte única de socializaçáo de pensamentos e posicionamentos acerca da homossexualidade: ora a igreja é, para alguns jovens, a principal autoridade explicativa, ora, para estes e para outros, ela perde o monopólio, o que resulta do crescente fluxo de trocas simbólicas no processo de formação dos sujeitos no mundo contemporâneo. Esse parece ser o caso de parcela significativa dos jovens da periferia que se deslocam em direção a uma igreja no centro, no ambiente da classe média e da sociabilidade LGBT, e que são provocados a reconfigurar seus modos de pensar as dissidências de gosto sexual.

Para se aprofundar o conhecimento acerca dos enlaces entre religião, moralidades, geração, fase da vida, sexualidades e regulação institucional, algumas perguntas de pesquisa são relevantes: o que o fiel faz com aquilo que a igreja quer fazer dele? O que ele faz com o que as outras instâncias sociais, como a rua, querem fazer dele? Os sinais dos tempos e dos lugares nos dirão o que ele quer fazer com essa rua e com essa igreja para que elas sejam dele. Somente assim é possível compreender o sujeito como participante de seu processo socializador e de sua cultura, visto que ele não é mero reprodutor de sistemas simbólicos aparentemente coerentes, mas um sujeito que se envolve afetivamente nas lutas e violências simbólicas, socializando seu modo de pensar não apenas as dissidências dos outros, mas também as suas próprias, e criando, com isso, formas de aproximaçáo e familiaridade entre gostos sexuais e fé. 
ELIAS EVANGELISTA GOMES. SINAIS DOS TEMPOS; SINAIS DOS LUGARES...

\section{Notas}

1 Uma versão próxima a este artigo foi publicada em inglês na Virtual Brazilian Anthropology (Gomes, 2010a). Na presente versão, atualizo a expressão desejo afetivo-sexual para gosto sexual e suas implicaçóes no ambiente pesquisado.

2 Alerto o leitor para algumas diferenças de grafia ao longo do texto, a saber: conteúdos entre aspas duplas são falas literais dos pesquisados ou dos autores respectivamente citados; aspas simples são grifos do autor deste artigo; termos em itálico são conceitos deste mesmo autor e de demais autores.

3 Esclareço que esse 'encontro' é uma espécie de encontro antropológico entre sujeitos, sem, contudo, haver uma adesão à homossexualidade como vivência desse gosto para si mesmo.

4 Inspirado no uso do conceito de configuração, de Norbert Elias (1970), por Maria da Graça J. Setton (2002) para explicar a interdependência das instâncias socializadoras, entendo que igreja, rua e jovem/fiel não são estruturas metafísicas que existem acima uns dos outros, mas estão em permanente e dinâmica relação.

5 A pesquisa em Belo Horizonte foi realizada na Universidade Federal de Minas Gerais (UfMG) e contou com o apoio da Pró-Reitoria de Extensão. A investigação em São Paulo teve o apoio da Fundação de Amparo à Pesquisa do Estado de São Paulo (Fapesp), por meio do processo 07/52292, e esteve parcialmente integrada a uma cooperaçáo internacional (Capes-Cofecub) entre pesquisadores das seguintes instituições: Universidade de São Paulo (USP), Universidade Estadual de Campinas (Unicamp), Centro Brasileiro de Análise e Planejamento (Cebrap), Université de Toulouse II e École des Hautes Études en Sciences Sociales (Ehess).

6 Em certa ocasião, o bispo da Sara Nossa Terra no Estado de São Paulo me questionou: "Você já percebeu que aqui a gente fala mais em céu que em inferno?". De fato, ele almejava saber se eu havia observado, como pesquisador, as distinçóes entre as igrejas no que se refere às suas práticas e noçóes. Jair de Almeida Júnior (2008) elaborou uma classificação, no interior da onda neopentecostal, em que aponta duas tendências importantes: a) neopentecostalismo rústico, aquele em que os princípios mágicos são mais persistentes, representado principalmente pela Igreja Universal do Reino de Deus, na qual a figura do diabo tem entrada livre e é perseguida como tal; e b) alto pentecostalismo, formado por um público mais escolarizado, embora inicialmente ligado à noção de maldiçóes hereditárias, com uma ênfase nitidamente menor em ritos e objetos mágicos 
REVISTA DE ANTROPOLOGIA, SÃO PAULO, USP, $20 \mathrm{I}$, V. 58 N $\mathrm{N}^{\mathrm{O}} \mathrm{I}$.

e maior destaque ao "céu", cuja principal referência é a própria Comunidade Evangélica Sara Nossa Terra.

7 Localizei, na literatura sobre sexualidade, o uso da expressão gosto sexual, mas ela até então não havia tomado significado para mim. Não encontrei nenhum autor que a interpela conceitual e teoricamente, sendo, em geral, usada como recurso linguístico comum. Certamente, as teorias da construção social da sexualidade, presentes em estudos como os de Michel Foucault, Jeffrey Weeks, Carole Vance, Mary McIntosh e nos estudos queer, corroboram um entendimento, uma fundamentação e uma problematização mais amplos do conceito, mas, por ora, Bourdieu atende parcialmente aos interesses deste artigo.

8 Em outros trabalhos, interpelo teoricamente as categorias de exercício do sexo e de agendamento da sexualidade. A pornografia é outro espaço de encontro com a diversidade sexual por meio do qual os meninos de todos os gostos sexuais, mais do que as meninas, organizam seus modos de julgar, hierarquizar e conceber o corpo, o gênero, o sexo, o prazer (Gomes, 2015). Aqui, sexo oposto e mesmo sexo referem-se às pessoas designadas, ao nascer, mulheres e homens, sexo feminino e sexo masculino, respectivamente. São categorias que confrontam e delimitam uma gama de experiências e apropriaçóes da sexualidade e, no cotidiano dos sujeitos, essencializam aspectos do sexo e das identidades. Elas formam delimitaçôes e restriçóes para os reconhecimentos da diversidade dos trânsitos, das performances e das experiências sexuais. Segundo Judith Butler (2003: 164), "a categoria sexo não é nem invariável nem natural, mas sim um uso especificamente político da categoria natureza" e "conceitos, categorias e abstraçôes" cometem certas violências contra os corpos aos quais se pretende atribui-los 9 Em outro trabalho, pude tratar melhor sobre o tema do agendamento da sexualidade. A saber: o caráter temporal equivale a uma sequência de eventos afetivos (orar, namorar, noivar e casar); o de orientaçáo, por sua vez, a um tipo de relação restrita entre pessoas de sexos opostos.

10 Lair Ribeiro, brasileiro, é classificado como autor de "autoajuda". Muito lido, ele é criticado por aqueles que possuem gostos culturais tidos como mais refinados. Essa comparação com a teologia da prosperidade evidencia os modos de julgar e hierarquizar práticas culturais e crenças na disputa do campo evangélico.

11 Denomino por práticas mágicas: exorcismos, quedas de pessoas para trás, uso de objetos que simbolicamente portariam milagres (sal grosso, flores etc.). Na igreja pesquisada (Sara - Rua Augusta), observei certo declínio dessas práticas, o que está diretamente ligado ao seu modo de pensar a sexualidade e suas dissidências. 
ELIAS EVANGELISTA GOMES. SINAIS DOS TEMPOS; SINAIS DOS LUGARES...

Porém, ao ir a outro templo, no Estado do Tocantins, observei que muitas pessoas, durante o culto, caíam deitadas no chão, "cheias do Espírito Santo". Um fenômeno um tanto incômodo para um jovem de classe média da igreja, visto que "as pessoas caem até por modismo, porque está na moda cair”.

12 Trata-se de um modelo de organização eclesial que tem sido replicado com especificidades locais em diversas denominaçóes brasileiras, principalmente nas igrejas $\mathrm{da}$ onda neopentecostal. Na medida em que essas denominaçôes crescem em volume de fiéis, busca-se dispor de estratégias de controle por meio de pequenos grupos (Gomes, 2010b, 2012a).

13 Em 2006, o Bispo Robson Rodovalho, fundador da Comunidade Evangélica Sara Nossa Terra, foi eleito Deputado Federal para representar o Distrito Federal pelo Partido da Frente Liberal (PFL), que veio depois a se chamar Democratas (DEM). Em 2008, ele foi nomeado Secretário do Trabalho no governo de José Roberto Arruda, governador do DEM cassado após envolvimento no caso conhecido como "Mensalão do DEM". O deputado sofreu pedido de cassação de mandato por infidelidade partidária, terminou o mandato no Partido Progressista (PP) e não foi candidato à reeleição em 2010.

14 O conceito de pânico moral, originalmente formulado pela sociologia britânica, é entendido por Erich Goode e Nachman Ben-Yehuda (2009) como um consenso, entre certo número de pessoas, de que há outros grupos ou práticas que póem em risco a ordem social, necessitando-se de esforço e unidade no combate às ameaças. O conceito de pânico sexual foi enfatizado por Carole Vance e Gayle Rubin, nos Estados Unidos, como uma chave analítica para compreender processos de repulsão aos sujeitos que vivenciam práticas sexuais dissidentes (Piscitelli et al., 2004). No Brasil, Richard Miskolci (2007) afirma que os pânicos morais emergem a partir do medo social relacionado às mudanças, entre elas, a união civil entre pessoas do mesmo sexo - o "casamento gay". Esse pânico busca disseminar "medo" com relação aos comportamentos não convencionais, às conjugalidades e práticas culturais consideradas "ameaçadoras".

15 O discurso de "acolhida e transformação" também foi observado em outras pesquisas (Natividade, 2006; Natividade e Oliveira, 2009).

16 Embora a tônica psicologizante seja forte nessa denominação, há persistência de chaves analíticas que associam as dissidências sexuais a noçóes de males espirituais, expressas como "investidas" e "tentaçôes" do "inimigo [diabo]". Esse discurso atravessa diferentes esferas da vida e denominaçóes (Mariz, 1997; Birman, 1997), sendo que sua persistência resulta do trânsito de cosmologias e fiéis entre os templos e denominaçóes. 
REVISTA DE ANTROPOLOGIA, SÃO PAULO, USP, $20 \mathrm{I}$, V. 58 N $\mathrm{N}^{\mathrm{O}} \mathrm{I}$.

Ou seja, mesmo que haja uma decadência de parte das explicaçóes espirituais, pontos significativos persistem entre os fiéis mais propensos ao discurso pentecostal tradicional.

17 Em outro trabalho, tive oportunidade de ofertar maiores detalhes sobre as práticas de socialização entre jovens evangélicos, analisando o circuito de trocas simbólicas em torno da sexualidade a partir de uma inspiração maussiana (Gomes, 2012a).

18 Observei três modalidades de cuidado em relação à sexualidade entre os jovens: 'compartilhado', em que os jovens líderes de grupos do G12 compartilham com líderes adultos e pastores a tarefa de ouvir e ensinar sobre o agendamento da sexualidade, pelo fato de se considerarem e serem considerados imaturos e também por, às vezes, vivenciarem as mesmas crises; um 'cuidado autônomo', em que os jovens líderes negociam diferentes princípios sobre sexualidade, não se limitando ao agendamento proposto pela igreja, mas, por exemplo, indicando o uso de preservativos quando não se deveria fazer sexo ou se posicionar favorável à vivência do gosto sexual pelo mesmo sexo; e um 'autocuidado', em que o jovem (tanto na posição de líder quanto na de discípulo) não compartilha aspectos de sua sexualidade com seus líderes para que não seja cuidado por alguém que não compartilha das mesmas percepçóes. Observei que jovens de todos os gostos sexuais (pelo mesmo sexo e pelo sexo oposto) perpassam pelas três modalidades tanto no que se refere às suas próprias sexualidades, quanto no que se refere às de seus discípulos. A igreja possui um grupo para o discipulado de "pessoas que tenham problema com a questáo G", ou seja, pessoas de gostos dissidentes, homossexuais.

19 No campo, observei que, ao mesmo tempo em que os jovens aderem a uma perspectiva de autonomia na construção de percepçôes de mundo, são também conduzidos minuciosamente por algumas das condiçóes de socialização a que estão submetidos. Portanto, naquilo em que os jovens são controlados pela igreja, eles são coniventes com o controle, mesmo que em diversos momentos manifestassem tensóes e resistências iniciais ou, ainda, se submetessem a certa "dominação" por determinado tempo e depois a rompessem.

20 O termo 'segurança de gosto sexual' não é uma categoria êmica, mas uma forma de condensar aspectos dos modos de perceber, classificar, julgar e compreender as expressóes sobre a sexualidade. Ter segurança de gosto sexual é ter certeza, garantia, firmeza dos modos de ser, pensar e agir no âmbito da sexualidade. São provas públicas e íntimas pelas quais os sujeitos têm certa nitidez dos gostos, geralmente expressa pela convicção do que se é, de quem se gosta, do que se gosta, do que se aprecia e do que se refuta. Trata-se de respostas em termos de performances 
ELIAS EVANGELISTA GOMES. SINAIS DOS TEMPOS; SINAIS DOS LUGARES...

corporais, interações sociais e histórico afetivo que se oferecem para que haja reconhecimento como tal. A expressão da segurança de gosto nem sempre corresponde às experiências vividas e, por vezes, quando essas duas dimensóes são vistas como ambíguas e híbridas, geram-se acusaçôes para os sujeitos que não expressam a segurança de gosto sexual pelo sexo oposto.

21 O cuidado socializador para reconversão de gosto sexual da parte dos meninos heterossexuais autodeclarados é bastante experimental e pouco se conhece do "universo gay" e de suas "artimanhas" (banheiro público, clube de sexo de homens, dark room etc.). Segundo dissidentes de gosto sexual pelo mesmo sexo, não se relatam "essas coisas" ao líder para que ele não se "assuste", ou seja, para que o estranhamento, o julgamento e a hierarquização de gostos não sejam maiores, distanciando ainda mais os sujeitos na incitação a "antigos preconceitos".

22 Ronaldo de Almeida (2004) utiliza como dado empírico o contexto da Igreja Universal do Reino de Deus e da Igreja Assembléia de Deus.

23 O espaço urbano da sexualidade no qual a igreja se localiza é estratificado a partir de linguagens, hábitos e gostos culturais. Os fluxos dos prazeres dissidentes e seus sujeitos na região da Rua Vieira de Carvalho, da Rua Augusta e da Avenida Paulista, entre outros circuitos, não perdem de vista os marcadores sociais de diferença (cor, classe, etapa da vida, gênero) que, por vezes, servem tanto para demarcação social dos frequentadores quanto para a "transgressão erótica" dos fluxos urbanos e dos sujeitos (Simóes, 2004; Braz, 2009).

24 Gilberto Velho (1999), quando pesquisou o bairro de Copacabana na cidade do Rio de Janeiro, identificou que a moradia na região ou a frequência a essa localidade colocava os sujeitos em uma situaçáo de prestígio e reconhecimento social que lhes atribuía certo estatuto de ascensão social. Por vezes, o deslocamento do bairro (subúrbio) ao centro não é vivido de forma tranquila, mas marcado por tensóes e acusaçóes por parte daqueles que não o fizeram.

25 Utilizo o termo pragmático sob a possibilidade de rasurá-lo brevemente a partir de outras construçôes teóricas acerca da formação social do gosto sexual na igreja evangélica. Nesse caso, penso naqueles jovens da igreja que vão à Parada do Orgulho LGBT para "ficar com meninas" e vender alimentos com o propósito de ganhar dinheiro para seus grupos de jovens da igreja.

26 A baixa declaração de "simpatia" ou de desfocamento da sexualidade como fenômeno importante na experiência de fé deve-se, sobretudo, ao modo como estão hierarquizados os gostos sexuais pelo sexo oposto por valor heteronormativo 
REVISTA DE ANTROPOLOGIA, SÃO PAULO, USP, $20 \mathrm{I}$, V. 58 N $\mathrm{N}^{\mathrm{O}} \mathrm{I}$.

(Chambers, 2003; Cohen, 2005). Nesse sentido, os sujeitos que se aproximam de um modelo de "simpatia" pelos sujeitos com suas práticas não declaram seus novos pensamentos no grupo para que não sejam "julgados" como "fora dos princípios de Deus" ou fora dos princípios da heterossexualidade.

27 Na Sara Nossa Terra, sabe-se que classe social é um marcador de diferença importante no grupo de jovens e na igreja. Alguns autores escreveram sobre o ethos próprio de camadas populares (Fonseca, 2000; Duarte, 1987) e de camadas médias (Velho, 1999; 2003) no Brasil, chaves interpretativas relevantes para o prosseguimento deste estudo. Dados os limites deste artigo, devo considerar que, apesar de não ser abordada aqui, a escolarização é outro marcador de diferença que influi significativamente sobre a fixação e/ou as mudanças de percepções acerca das dissidências sexuais.

\section{Referências bibliográficas}

Almeida, R.

2004 "Religião na metrópole paulista”. RBCS, São Paulo, vol. 19, n. 56: 15-27.

Almeida Junior, J.

2008 "Um panorama do fenômeno religioso brasileiro". Ciências da Religiäo - História e Sociedade, São Paulo, vol. 6, n. 2: 146-177.

Amorese, R.

1995 A igreja evangélica na virada do milênio: a missão da igreja em um país em crise. Brasília, Comunicarte \& AEvB.

Birman, P.

1997 "Males e malefícios no discurso neopentecostal". In Birman, P.; Novaes, R. R.; Crespo, S. (orgs.), O mal à brasileira. Rio de Janeiro, Eduerj, pp. 62-80.

Bourdieu, P.

1996 Razóes práticas: sobre a teoria da açâo, Campinas, Papirus Editora.

2002 "Modos de dominaçáo". In Setton, M. G. J. (org.), A produção da crença: contribuição para uma economia dos bens simbólicos / Pierre Bourdieu. São Paulo, Editora Zouk.

2003 Questōes de sociologia. Lisboa, Fim de Século - Ediçōes, Sociedade, LDA.

2008 A distinção: crítica social do julgamento. Porto Alegre, Editora Zouk. 
ELIAS EVANGELISTA GOMES. SINAIS DOS TEMPOS; SINAIS DOS LUGARES...

Bozon, M.

2004 Sociologia da sexualidade. Rio de Janeiro, FGV.

Braz, C. A.

2009 "Silêncio, suor e sexo: subjetividades e diferenças em clubes para homens". In Díaz-Benítez, M. E. \& Fígari, C. E. (orgs.), Prazeres dissidentes. Rio de Janeiro, Garamond, pp. 207-236.

ButLer, J.

2003 Problemas de gênero: feminismo e subversão da identidade. Rio de Janeiro, Civilização Brasileira.

Chambers, S. J.

2003 "Telepistemology of the Closet; Or, the Queer Politics of Six Feet Under". Journal of American Culture, vol. 26, n. 1: 24-41.

Cohen, C. J.

2005 "Punks, bulldaggers, and welfare queen: the radical potential of queer politics?". In Johnson, E. \& Henderson, M. G. (eds.), Black Queer Studies. Duke, Duke University Press, pp. 22-51.

Duarte, L. F. D.

1987 "Pouca vergonha, muita vergonha: sexo e moralidade entre as classes trabalhadoras urbanas". In Lopes, J. S. L. (org.), Cultura e identidade operária. São Paulo, Marco Zero.

2005 "Ethos privado e justificação religiosa: negociações da reprodução na sociedade brasileira”. In Heilborn, M. L. et al. (orgs.), Sexualidade, família e ethos religioso. Rio de Janeiro, Garamond, pp. 137-176.

Dumont, L.

1992 Ensaios sobre o individualismo: uma perspectiva antropológica sobre a ideologia moderna. Lisboa, Dom Quixote.

1997 Homo hierarchicus: o sistema de castas e suas implicaçôes. São Paulo, Edusp, 2 ed.

Elias, N.

1970 Introdução à sociologia. Lisboa, Ediçôes 70. 
REVISTA DE ANTROPOLOGIA, SÃO PAULO, USP, $20 \mathrm{I}$, V. 58 N $\mathrm{N}^{\mathrm{O}} \mathrm{I}$.

Elias, N. \& Scotson, J.

2000 Os estabelecidos e os outsiders. Rio de Janeiro, Jorge Zahar Editor.

FAVRET-SAADA, J.

2005 "Ser afetado". Cadernos de Campo, São Paulo, n. 13, ano 14: 155-161.

Fonseca, A. B. C.

1998 "Nova era evangélica, confissão positiva e o crescimento dos Sem Religião". In VIII Jornadas sobre alternativas religiosas na América Latina, Sáo Paulo, Editora da USP.

FonseCA, C.

2000 Família, fofoca e honra: etnografia de relaçöes de gênero e violência em grupos populares. Porto Alegre, Editora da Ufrgs.

Foucault, M

1988 História da sexualidade I: a vontade de saber. Rio de Janeiro, Ediçôes Graal.

Giddens, A.

1991 As consequências da modernidade. Editora Unesp, São Paulo.

Gomes, E. E.

2007a "Jovens que soltam o som do céu na terra: apontamentos etnográficos sobre um grupo de louvor". Revista Três Pontos, Belo Horizonte, vol. 1, n. 6: 27-34.

2007b "No bairro tem igreja: práticas culturais entre jovens pentecostais". Cadernos do CERU, São Paulo, n. 18: 68-78.

2010a "In the church and the street: reconfigurations of ways of thinking about affective and sexual desire for people of the same sex". Virtual Brazilian Anthropology, Florianópolis, vol. 7: 191-220.

2010 b "A socialização no aprisco do Senhor". Cadernos do CERU, São Paulo, vol. 1, n. 2: 281-304.

2012a "Nas tramas da socializaçáo: uma análise socioantropológica sobre sexualidade juvenil na religião". Cadernos Cenpec, São Paulo, vol. 2, n. 2: 65-87.

2012 b "Festa e pós-festa: a socialização de jovens evangélicos na metrópole". In MeLLo, L. et al. (orgs.), Questôes de sociologia: debates contemporâneos, Goiânia, pp. 51-71.

2015 "Práticas socializadoras do gosto sexual e do exercício do sexo". Etnográfica, Lisboa, v. 19, n. 1: 51-75. 
ELIAS EVANGELISTA GOMES. SINAIS DOS TEMPOS; SINAIS DOS LUGARES...

Goode, E. \& Ben-Yehuda, N.

2009 Moral panics: the social construction of deviance. Malden, Wiley-Blackwell Publishing.

Jesus, F. W.

2010 A cruz e o arco íris: refletindo sobre gênero e sexualidade a partir de uma "igreja inclusiva” no Brasil”. Ciências sociais e religiāo, Porto Alegre, n. 12: 131-146.

LAHIRE, B.

2006 A cultura dos indivíduos. Porto Alegre, Ed. Artmed.

Magnani, J. G. C.

2005 “Os circuitos juvenis urbanos". Tempo Social, São Paulo, vol. 17, n. 2: 173-205.

Mariano, R.

1999 Neopentecostais: sociologia do novo pentecostalismo no Brasil. São Paulo, Loyola.

Mariz, C. L.

1997 "O demônio e os pentecostais no Brasil". In Birman, P.; Novaes, R. R. \& Crespo, S. (orgs.), O mal à brasileira. Rio de Janeiro, Eduerj, pp. 45-61.

Mauss, $\mathrm{M}$

2003 Sociologia e antropologia. São Paulo, Cosac Naify.

Miskolci, R.

2007 "Pânicos morais e controle social: reflexōes sobre o casamento gay". Cadernos Pagu, n. 28: 101-128.

Natividade, M.

2003 "Carreiras homossexuais no contexto do pentecostalismo: dilemas e soluçōes". Religião \& Sociedade, vol. 23, n. 1: 132-152.

2006 "Homossexualidade, gênero e cura em perspectivas pastorais evangélicas". RBCS, São Paulo, vol. 21, n. 61: 115-132.

2008 Deus me aceita como en sou? A disputa sobre o significado da homossexualidade entre evangélicos no Brasil. Rio de Janeiro, tese, UFRJ. 
REVISTA DE ANTROPOLOGIA, SÃO PAULO, USP, $20 \mathrm{I}$, V. 58 N $\mathrm{N}^{\mathrm{O}} \mathrm{I}$.

Natividade, M. \& Oliveira, L.

2004 "Algumas tendências recentes nos discursos evangélico e católico sobre a homossexualidade". Sexualidade, Gênero e Sociedade, ano XI, n. 22: 1-5.

2009 "Sexualidades ameaçadoras: religião e homofobia(s) em discursos evangélicos conservadores". Sexualidad, Salud y Sociedad, Revista Latinoamericana, n. 2: 121-161.

Novaes, R. R.

2001 "Juventude e religião: marcos geracionais e novas modalidades sincréticas". In SAnchis, P. (org.), Fiéis \& cidadãos: percursos de sincretismo no Brasil. Rio de Janeiro, Eduerj, pp. 181-207.

2006 “Os jovens de hoje: contextos, diferenças e trajetórias". In Almeida, M. I. M. \& Eugênio, F. (orgs.), Culturas jovens: novos mapas do afeto. Rio de Janeiro, Jorge Zahar Editor, pp. 105-120.

Oro, A. P.

1997 "Neopentecostais e afro-brasileiros: quem vencerá esta guerra?". Debates do NER, n. 1: 10-36.

PAIs, J. M.

1993 Culturas juvenis. Lisboa: Imprensa Nacional Casa da Moeda.

Piscitelli, A.; Gregori, M. F. \& Carrara, S. (orgs.)

2004 Sexualidade e saberes: convençôes e fronteiras. Rio de Janeiro, Garamond.

Setton, M. G. J.

2002 "Família, escola e mídia: um campo com novas configuraçôes". Educação e Pesquisa, São Paulo, vol. 28, n. 1: 107-116.

2005 "A particularidade do processo de socialização contemporâneo". Tempo Social, São Paulo, vol. 17, n. 2: 335-350.

2009 A socialização como fato social total: um ensaio sobre a teoria do habitus. São Paulo, tese, USP.

Simôes, J. A.

2004 "Homossexualidade masculina e curso da vida: pensando idades e identidades sexuais". In Piscitelli, A. et al. (orgs.), Sexualidade e saberes: convençóes e fronteiras. Rio de Janeiro, Garamond, pp. 415-447. 
ELIAS EVANGELISTA GOMES. SINAIS DOS TEMPOS; SINAIS DOS LUGARES...

Telles, V. S. \& Cabanes, R. (orgs.)

2006 Nas tramas da cidade: trajetórias urbanas e seus territórios. São Paulo, Humanitas (Estudos Urbanos).

VELHO, G.

1999 Individualismo e cultura: notas para uma antropologia da sociedade contemporânea. Rio de Janeiro, Jorge Zahar. urbanas: desafios do trabalho antropológico. Rio de Janeiro, Jorge Zahar Editor.

Signs of the Times, Signs of Places: Reconfigurations of the Ways Heterosexuals Think the Sexual Likes of Homosexuals

ABSTRACT: From an ethnography carried out in an evangelical church in the city of São Paulo (Brazil), this article discusses the nexus between religion and sexuality in the urban context. Through what some self-proclaimed heterosexual young churchgoers in question, it was possible to reflect on aspects of classification, hierarchy and judgment related to dissident sexual likes. More specifically, we seek here to analyze the emergence and decline of cosmologies, discourses and socializing strategies on homosexuality among evangelicals. It also examines conceiving modes and relate with dissent around the moralities and expressions of sexuality within the church and in urban environments of sociability. The article presents, finally, a reflection on the movement of people between different social worlds and on the modes in which these youngsters reconfigure the sense of religion and sexuality.

KEYWORDS: Sexual Likes, Homosexuality, Youth, Evangelicals, Socialization.

Recebido em novembro de 2013. Aceito em dezembro de 2014. 